\title{
Factors Influencing E-Procurement Practice in Pakistan
}

\author{
Amish Aqeel (Corresponding author) \\ Karachi University Business School \\ University of Karachi, Karachi, Pakistan
}

Tel: 92-331-276-6424Ｅ-mail: amishaqeel@gmail.com

\author{
Dr. Muhammad Asim \\ Associate Professor, Karachi University Business School \\ Karachi University Business School, University of Karachi, Karachi, Pakistan \\ Tel: 92-333-348-5884Ｅ-mail: masimku@hotmil.com
}

Received: July 12, 2019 Accepted: July 26, 2019 Published: July 29, 2019

doi:10.5296/bms.v10i2.15073 URL: https://doi.org/10.5296/bms.v10i2.15073

\begin{abstract}
The concept of E-procurement has been widely spread with the growing use of informational technology in every field. Organizations are adopting methods of procurements that are more reliable, less time consuming and relatively stronger than the traditional methods. This quantitative study investigates factors influencing e-procurement practice in Karachi, Pakistan. A sample of 319 respondents was taken to observe the influence of internal organizational support, integration with suppliers' electronic systems, supplier willingness, perceived improvements to purchasing tasks and supplier pressure on e-procurement intention. The results information indicates that internal organizational support, supplier willingness and perceived improvements to purchasing tasks significantly influences e-procurement intentions. However, the factors integration with suppliers' electronic systems and supplier pressure does not have any significant impact on e-procurement intention. The result recommends the use of e-procurement system for organizations to facilitate the current practices of procurement.
\end{abstract}

Keywords: Internal Organizational Support (IOS), Integration with Suppliers' Electronic 
Systems (ISES), Supplier Willingness (SW), Perceived Improvements to Purchasing Tasks (PIPT), Supplier Pressure (SP), E-Procurement Intention (EPI)

\section{Introduction}

\subsection{Background of Study}

E-procurement is defined as an e-commerce tool that refers to all processes relating to the purchase of goods and services over the Internet. From the point of B2B (business to business) is a means of facilitating purchasing (or procurement) management by reducing procurement costs (time spent on demand). Following Porter's (2001) reasoning on integrating e-commerce with strategy to gain competitive advantage, the incorporation of e-procurement in its business strategy would lead the company to a significant reduction in time by the buyer with operating activities and low value-added activities and mainly a decrease in costs the entire procurement cycle. Franco (2003) shows certain benefits for the company with the use of e-procurement, such as: significantly reduces procurement costs; lays down adaptive, efficient and collaborative relationships with suppliers; enables you to monitor the buyer behavior; improve sources by discovering more suppliers; allows flexible access to purchasing information anytime, anywhere.

The word comes from the English electronic procurement refers to the buying and selling of products and services through the internet. Typically, e-procurement sites allow qualified and registered users to find buyers or suppliers of specialized products and / or services, which are often difficult to locate among the contacts of purchasing or sales teams. (Gunasekaran McGaughey Ngai\& Rai 2009). Depending on the approach, buyers or sellers can forecast prizes or bid according to the volume traded, for example, creating a competition that can especially benefit the company they are buying. The development of e-commerce (EC) technologies, involving the use of the Internet to the business, has created numerous opportunities for managers effectively shape and direct their supply chains competitive. In this sense, Information Technology (IT), more precisely the Internet, a prominent role in the acquisition of competitive advantage by the companies; as early as 1985 Porter and Millar (1985) cite that IT participates in the value chain and transforms the way value activities are carried out and the transformations in nature of the links between them. This transformation not only affects the competitive, it also reshapes the way products meet buyer's needs. More specifically, the Internet has changed the way you do business.

According to Lancioni, Smith and Oliva (2000), the Internet makes it possible to increase of communication between consumers and their suppliers, improving the levels of service and reducing logistics costs. In this context, one of the activities of that has caused great impact on the company are the functions related to e-procurement. E-procurement is part of so-called information technology. The settings are varied. Presutti (2003 , p. 221), for example, defines e-procurement as "a technological solution that facilitates corporate purchases through the use of the internet". For min and galle (2003), e-procurement refers to business-to-business transactions that use e-commerce to identify potential sources of supplies, to buy goods and 
services, to make payments and to interact with suppliers.

According to $\mathrm{Wu}$, Zsidisin and Ross (2007) e-procurement is defined as the use of information technology to facilitate $b 2 b$ purchasing transactions of materials and services. On the other hand, Angeles and Nath (2007), also define as being purchases of products and services by companies through the internet. At the same time, since the late 1990s, various e-commerce technologies have emerged with the promise of revolutionizing work practices, threatening existing enterprises, and potentially creating new business models in the supply chain (Smart, 2009). Following the growth of the use of electronic commerce in the business-to-business market, there was the globally significant adoption of e-procurement (Devaraj; Vaidyanathan; Mishra, 2012 ). This adoption is not limited to the private sector and public sector experiences are also beginning to be reported (Walker, Brammer, 2012 , Costa, Arantes, Tavares, 2013 , Van Greunen, Herselman and Van Niekerk, 2010 ). In addition, the use of e-procurement has been associated with sustainable practices, especially with the reduction of solid waste generation (Walker, Brammer, 2012 ; Costa, Arantes, Tavares, 2013 ).

The performance of the electronic contract has to have the same requirements of admissibility with regard to the traditional contract, as an example, be in line with the law. However, the peculiar characteristic that differentiates them is that the celebration of the electronic contract is done through the Internet, which has electronic networks and programs as a communication medium for its execution. In this way, we observe that electronic contracting is currently incorporated into the customs of society, so that it is already possible to enter into contracts through electronic means to acquire any product or service, including electronic contracting that has been used in several legal areas, such as such as consumerism, labor, international trade, administrative and so on.

Smart (2009) points out that the literature on e-procurement has been growing strongly since the late 1990s when articles dealing with the impact of the internet and e-commerce on supply chain management began to be published. The purpose of this article is to conduct a study on the evolution of e-procurement. The survey sought to understand e-procurement practices in companies, identifying existing models, advantages, benefits, critical implementation factors and difficulties in their use.

\subsection{Objectives of Study}

1. To investigate the effect of internal organizational support on electronic procurement intentions (epi) - e-recruitment intention

2. To explore whether integration with suppliers' electronic systems impact on epi

3. To identify supplier willingness on electronic procurement intentions

4. To find out the impact of perceived improvements to purchasing tasks on electronic procurement intentions 
5. To investigate the impact of supplier pressure on electronic procurement intentions

\subsection{Statement of the Problem}

The changes generated by the adoption of this new procurement process should be analyzed in order to guide how they will occur. There should be some steps for analyzing the e-procurement procedures such as identifying changes in processes, skills necessary for employees to carry out new activities and the changes in the functions of the employees. It is crucial to determine what will be done and who will be responsible for the execution. The organizational environment changes radically with the adoption in e-procurement, thus the factors that influence e-procurement processes must be addressed.

\subsection{Significance of the Study}

In general, it was verified that technology could bring several benefits to the user companies. It cannot only benefit in relation to the reduction of the costs involved in the purchase process but also aids in reduction of redundancies, reduction of expenses with red tape in the process. However, one aspect to be highlighted is that has an impact on the supply chain, are the problems that can be perceived during implementation, such as the technological immaturity of the company and its suppliers. Thus, this work contributes as a source of information for bibliographic reviews and as an indication for other research on the subject, since it lists a good number of relevant articles published on e-procurement. For companies, this paper serves as a guide to consider existing models, the challenges involved in deployment, and the benefits that can be brought about with e-procurement.

\subsection{Research Question}

RQ1: Does internal organizational support on electronic procurement intentions (epi)?

RQ2: Does integration with suppliers' electronic systems impacts on electronic procurement intentions?

RQ3: Does the supplier willingness influence electronic procurement intentions?

RQ4: To find out the impact of perceived improvements to purchasing tasks on electronic procurement intentions?

RQ5: Does supplier pressure effects on electronic procurement intentions?

\subsection{Research Hypothesis}

H1: Internal Organizational Support does not impact on Electronic Procurement Intentions (EPI) - e-recruitment intention

H2: Integration with Suppliers' Electronic Systems does not impact on electronic procurement intentions

H3: Supplier Willingness does not impact on electronic procurement intentions

H4: Perceived Improvements to Purchasing Tasks do not impact on electronic procurement intentions 
H5: Supplier Pressure does not impact on electronic procurement intentions EPI

\subsection{Conceptual Framework}

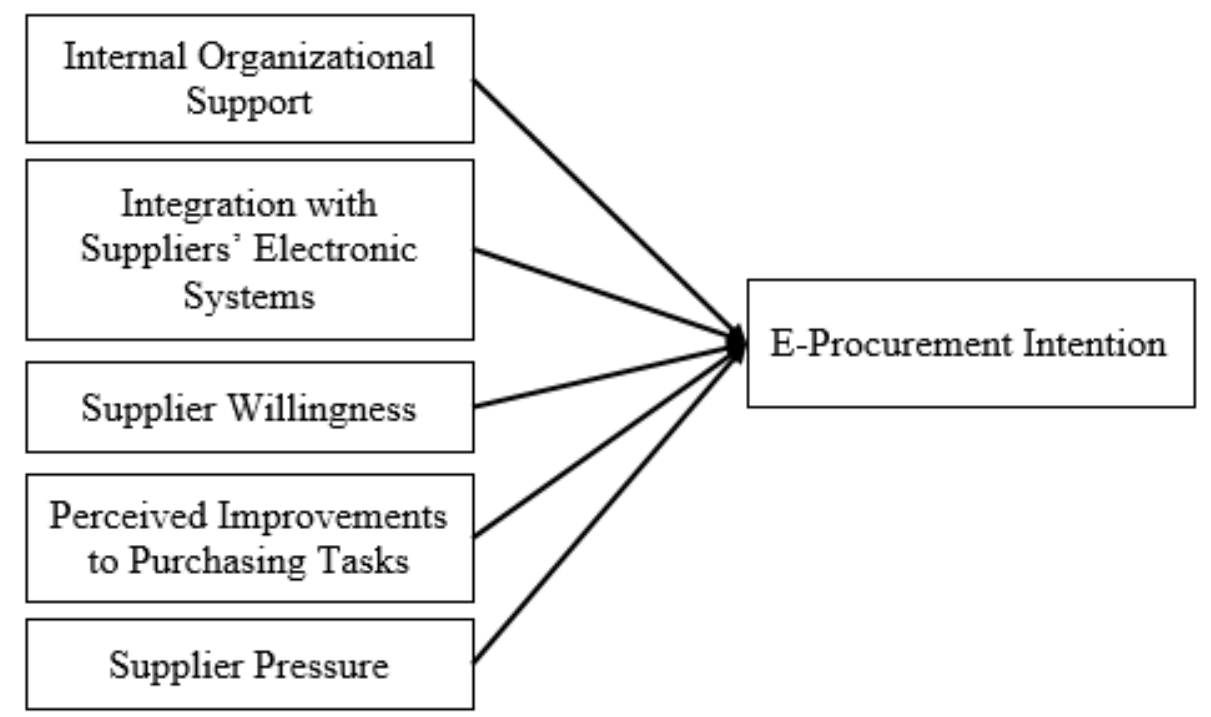

\section{Literature Review}

\subsection{E-Procurement}

E-procurement (electronic procurement) is an internet trading system that facilitates purchasing management. Companies to automate the process of purchasing goods use it and products, from order to payment, can be done manually or with the use of computer systems. Using the method gives companies more security when it comes to purchasing supplies. (Davila Gupta \& Palmer 2003). Thus, you create a reliable projection that can avoid large monetary losses for the business. It should avoid delays in the production or delivery of goods and also improves the logistics of the company, because when properly applied these issues become more functional.

E-procurement is defined as an e-commerce tool that refers to all processes relating to the purchase of goods and services over the Internet. From the point of B2B (business to business) is a means of facilitating purchasing (or procurement) management by reducing procurement costs (time spent on demand). Following Porter's (2001) reasoning on integrating e-commerce with strategy to gain competitive advantage, the incorporation of e-procurement in its business strategy would lead the company to a significant reduction in time by the buyer with operating activities and low value-added activities and mainly a decrease in costs the entire procurement cycle. Franco (2003) shows certain benefits for the company with the use of e-procurement, such as: significantly reduces procurement costs; lays down adaptive, efficient and collaborative relationships with suppliers; enables you to monitor the buyer behavior; improve sources by discovering more suppliers; allows flexible access to purchasing information anytime, anywhere. 
The word comes from the English electronic procurement refers to the buying and selling of products and services through the internet. Typically, e-procurement sites allow qualified and registered users to find buyers or suppliers of specialized products and / or services, which are often difficult to locate among the contacts of purchasing or sales teams. (Gunasekaran McGaughey Ngai\& Rai 2009). Depending on the approach, buyers or sellers can forecast prizes or bid according to the volume traded, for example, creating a competition that can especially benefit the company they are buying.

\subsection{History of E-Procurement}

Considering that by definition Procurement is a process of purchase and supply of products or services, probably its origin dates back to the beginning of commercial transactions around 3,000 BC. At this time in Egypt and Mesopotamia the Sumerians produced statues and artifacts in bronze, but there was no such metal in the region (Teo, Lin, \& Lai, 2009). Where was the raw material obtained? Certainly from other regions and peoples, already establishing a relationship of supply. Even before 2000 BC Mesopotamia obtained products from regions of Asia, there was an international market for supply and relations of interdependence.

Nearly 2,000 years later, in the Roman period, manuscripts describing supplies of ships and supplies of merchants to the Roman army can be found. In these supplies there were price negotiations and exemptions. Even at this time evidence can be found of the establishment of contracts between the parties, where conditions of supply and rewards were defined.If the Romans established commercial relations with private suppliers in contracts, it is from the medieval period that Procurement has major developments. (Dai, \& Kauffman,2001) At this time, there is a need to qualify suppliers, evaluate supply risks, quotations, establish strategic alliances, manage suppliers and of course formal bargaining and negotiation processes.

With the industrial revolution in England and the establishment of trade as the driving force of economic development, the relationship between supplier and buyer begins to contain elements of obligation and ethical behavior. (Zsidisin, \& Ross,2007). These elements become the basis for contracts and legal relationships. From then until the end of the twentieth century the Procurement function was consolidated, but without its importance recognized. It is considered an operational practice to buy products and services to satisfy functional needs. However, from the end of the 1980s Procurement began to undergo changes and quickly became a fundamental part of the Supply Chain concept. Procurement professionals come to have a vision of the whole company, being able to together with key functions generate value for the organization through the acquisition process.

\subsection{Types of procurement}

The following are the main types of e-procurement:

\subsubsection{Web-based ERP (Entrerprise Resource Planning)}

ERP solutions from companies such as SAP, AG, ORACLE, among others, designed to optimize a company's resource planning. In terms of the manufacturing process, they can 
generate the scheduling of purchases aiming at an ideal cycle of production.

\subsubsection{E-Sourcing}

This is the use of the Internet to identify new suppliers. Also known as a reverse auction, e-sourcing is the method by which companies can use their online purchasing process to contact a larger number of suppliers than would be possible in the traditional channel. The biggest benefit of e-sourcing is the competition between bidding vendors accompanied by the detail of the service they undertake to execute. Buyers have the task of selecting the best offer.

\subsubsection{E-Informing}

E-Procurement can be used for the simple mission of exchanging purchasing information between sellers and buyers. The use of Internet technology, such as email, as a substitute for traditional communication methods can greatly facilitate the process of assembling a supplier database.

\subsection{Benefits of E-procurement}

The electronic signature of documents has gained strength in Brazil in recent years. Not only because contracts signed electronically have legal value in the country since 2002, but also because many companies, such as 99, iFood, QuintoAndar and Caixa Seguradora, are concerned with adapting their business to the digital world. To save time and money on their internal processes, they use the services of DocuSign, a leading digital transaction management company with more than 200 million users in 188 countries and contracts with more than 300,000 customers. (Johnson, \& Klassen, 2005). The tools are available in 43 languages. "Whether in real estate, transportation or financial, reducing the dependence on paper brings many benefits, such as reducing up to $97 \%$ in the time of processing documents to complete a business.

In addition to being a more sustainable option, the solution allows the company to redesign its workflow so that it becomes more agile without the requirement to print, copy, send and store a document. See the case of the Insurance Fund. (Hardy, \& Williams, 2008). Since April this year, the company offers in all its branches the option of contracting life insurance through electronic signature.

According to Castelano Santos, Caixa Seguradora's product manager, the company sells more than 100,000 insurances per month. When the contract is physical, you need to print about five sheets. "Today, $40 \%$ of our sales are made with the electronic signature (Subramaniam, $\&$ Shaw,2004). Imagine how much paper we no longer use. This has a financial and ecological return, "says Santos. There is also a reduction in logistics costs. After all, the circulation of documents happens only through the internet, which reduces the investment to send letters and packages.

When they choose to work with electronic signatures, companies also streamline their 
processes. IFood, for example, had benefits with the agility of the electronic signature. In 2016, the leading online food delivery company in Brazil started using the DocuSign platform to reduce the negotiation time of the contracts it signed with new restaurants. Thanks to the change, the company closed the year with a growth of $237 \%$ in the number of new partners.

The sale of products with electronic signature also improves the experience of customers with brands. (Hardy, \& Williams,2008). The Caixa Seguradora, for example, noticed a quick adaptation to the digital contract model. "Customers are already accustomed to signing papers when they go to the bank, but they have become well accustomed to the idea of electronic signatures, a more agile and secure alternative," says Santos.

In addition to interacting with technology, customers are also able to access products that they buy faster, which increases the degree of satisfaction. Banco Inter, for example, adopted in September last year the electronic signature in the contracting of payroll-deductible loans. As a result, the completion time of the 14-day sale fell to eight days, resulting in an $18 \%$ reduction to $8 \%$ in the drop-off rate of customers seeking the product.

The electronic signature brings gains in both operational efficiency - there are companies that keep whole departments just to take care of the papers - as in the security of documents that deteriorate over time when they are printed (Subramaniam, \& Shaw,2004). With DocuSign solutions, everything is stored on servers with bank-level encryption and international security certificates. Moreover, once they are signed, contracts can no longer be changed, which puts an end to any risk of fraud. And the documents are available to be accessed at any time by smartphones, tablets or computers. In this way, the customer is never in danger of losing his copy of the contract. (Quesada, González, Mueller, \& Mueller,2010).

\subsection{Risk of e-procurement}

The risk management of suppliers is a preventive work in the company simulates or imagine scenarios of possible losses and creates processes and routines to avoid them. From the commercial relations with its current and possible suppliers, you can pre-determine what issues can arise regarding secrecy, privacy, and strategic policies, as well as evaluate performance. The purchasing team is directly involved in this work, but it is not her sole responsibility to do this management. Also involve financial, controller, legal and other departments. The risk management of suppliers is a concern of the modern company, since the hall of suppliers that serves it can be decisive in its competitiveness. A supplier's ability to meet demand with quality, good price and delivery efficiency and response time for possible logistics problems can make all the difference when it comes to relying on the raw material or components of a particular product (Croom \& Brandon-Jones, 2005).

In the medium and long term, this will be reflected in the productivity of the company and even in customer satisfaction (Subramaniam, \& Shaw,2004). Since the production chain (including receipt of third party products and services) must operate $100 \%$ in order for the final product or service to be delivered with quality and timely. 
It is necessary to observe the externalized characteristics referring to the facility of purchases of goods and services via the internet. Today is the vulnerability of the consumer in the performance of the contract.

However, there is a dizzying growth of purchases made via the internet, due to the convenience and facilitation caused to the consumer, since they can make a purchase without leaving home. (Quesada, González, Mueller, \& Mueller,2010). But, it is a fact, that the consumer often does not take the precautions prior to the purchase, in order to avoid any addiction. As a result, there have been repeated reports of fraud committed by companies and their partners on collective purchasing sites. Consequently, causing discomfort and dissatisfaction on the part of the internet consumer.

\subsection{E-Procurement Processes}

E-procurement is defined as an e-commerce tool that refers to all processes relating to the purchase of goods and services over the Internet. From the point of B2B (business to business) is a means of facilitating purchasing (or procurement) management by reducing procurement costs (time spent on demand). Following Porter's (2001) reasoning on integrating e-commerce with strategy to gain competitive advantage, the incorporation of e-procurement in its business strategy would lead the company to a significant reduction in time by the buyer with operating activities and low value-added activities and mainly a decrease in costs the entire procurement cycle. Franco (2003) shows certain benefits for the company with the use of e-procurement, such as: significantly reduces procurement costs; lays down adaptive, efficient and collaborative relationships with suppliers; enables you to monitor the buyer behavior; improve sources by discovering more suppliers; allows flexible access to purchasing information anytime, anywhere.

In general, it was verified that technology could bring several benefits to the user companies. It cannot only benefit in relation to the reduction of the costs involved in the purchase process but also aids in reduction of redundancies, reduction of expenses with red tape in the process. However, one aspect to be highlighted is that has an impact on the supply chain, are the problems that can be perceived during implementation, such as the technological immaturity of the company and its suppliers. Thus, this work contributes as a source of information for bibliographic reviews and as an indication for other research on the subject, since it lists a good number of relevant articles published on e-procurement. For companies, this paper serves as a guide to consider existing models, the challenges involved in deployment, and the benefits that can be brought about with e-procurement.

Contract in a simple and personal conception is called an agreement between two or more persons in manifestation of their will, where rights and obligations are established, as long as they are in conformity with the law and the principles that govern contracts in general. For Pablo Stolze Gagliano, the contract is a legal business by which the declaring parties, limited by the principles of social function and objective good faith, self-regulate the patrimonial effects that they intend to reach, according to the autonomy of their own wills. (GAGLIANO, 
Pablo Stolze, 2003, p.11). Thus, we cannot speak of a contract without mentioning three important points. Priori, the two fundamental principles that are a prerequisite in contracts based on the new civil code are: the principle of the social function that is the most important principle with regard to the modern. Theory of Contracts, a discipline that the contract has to be celebrated with the purpose of protecting every society and not only the personal interests of the parties. The second point, but no less important is the principle of objective good faith which states that the parties must act with loyalty and suitability throughout the process of signing, and must be honest and forthcoming before, during and after the execution of the contract, where the basis of the contractual relationship is trust. It is important to emphasize the manifestation of the will, as mentioned above, since without the manifestation of the human will there is no legal business and, in the absence of a legal business, consequently there is no contract. (Chang, \& Wong, 2010). But, what will be contract electronic differ from the traditional contract. Electronic contracts have characteristics that are their own and, therefore, differentiate them from other contracts. The validity of this contract came to be questioned by some doctrinators, especially in relation to the evidentiary force. This questioning still persists for a minority of doctrine and is aggravated by the lack of specific norms that discipline them.

The performance of the electronic contract has to have the same requirements of admissibility with regard to the traditional contract, as an example, be in line with the law. However, the peculiar characteristic that differentiates them is that the celebration of the electronic contract is done through the Internet, which has electronic networks and programs as a communication medium for its execution. In this way, we observe that electronic contracting is currently incorporated into the customs of society, so that it is already possible to enter into contracts through electronic means to acquire any product or service, including electronic contracting that has been used in several legal areas, such as such as consumerism, labor, international trade, administrative and so on.

In the Brazilian legal system, there is still no express regulation regarding this type of hiring. This can lead to a number of issues and conflicts between parties, such as consumer protection issues, digital signatures, electronic mail and particularly data privacy. However, the Legislature is not inert in relation to electronic contracts. For, there are several sparse norms and several bills in progress in the National Congress, which refer, directly or indirectly, to the subject. Regarding the examples that the Legislative Branch has a tendency to present to society soon some legislation related to digital law, e-commerce and contracts concluded by the Internet, one can highlight, among others, Bill n 84, of 1999. Features of the Internet Agreement that facilitate its implementation. With the advent of the Internet as an intermediary instrument, it enabled the transactions and negotiations carried out. Thus, obstacles previously suffered, such as: distance between the different parts and time zone, now is no longer a problem, because the internet has overcome these obstacles. (Carayannis, $\&$ Popescu,2005). Taking into account that the contract made via the Internet is depersonalized, not requiring the physical presence of the parties and deterritorialized, as it can be carried out in any place or territory and at any time. (Croom, \& Brandon-Jones, 2005) 
For Cláudia Lima Marques, the phenomenon of hiring at a distance in electronic commerce with consumers is a challenging reality. (Croom, \& Brandon-Jones,2007). Let's look at its main phenomena (challenges) that have been overcome with the use of the Internet as an intermediary in contractual transactions. In the traditional contract it was necessary for the parties to be required to perform the contract, but with the use of the Internet as the intermediary of the contract, it occurred to the depersonalization, which is nothing more than the absence of the individual at the time of the contract. However, this absence in no way alters the functional essence of the contract made via the internet.

With regard to the materiality of the contract, dematerialization occurred. For making the contract via internet does not require the materiality of the contract in the paper itself. For in this case the contract plays a secondary role. The most important of the challenges would be the distance of the parties to the contract. However, with the use of the Internet mediating the transaction, the reterritorialization occurred that is the instantaneous exchange of data and information in the worldwide computer network, without there being any problems regarding the distance of the user, thus being able to carry out the contractual transaction between the parties, of different time zones and time zones. In addition, finally yet importantly, it is time, which, in particular, is one of the most notorious characteristics generated by the internet, because the temporality that refers to the speed at which the information reaches the user occurred. (Teo, Lin, \& Lai, 2009) The time element deserves special attention because on the internet the concept of this time suffers some relativization. It is important to note that because of the globality of the internet,

It is observed that the distance, the time, as well as the place, are no longer obstacles to the realization of a contract. (Quesada, González, Mueller,\& Mueller,2010). For, the internet was a remarkable and indispensable instrument for the accomplishment of this overcoming, that is, with the advent of the internet in legal business, phenomena such as: time, place, distance, speed, all of which in what could previously be challenges or obstacles to the realization of a contract, today are no longer challenging phenomena. (Subramaniam, \& Shaw,2004). For with the use of the Internet, as a facilitator in the execution of the contracts, previously called, traditional contracts and today with the intermediation of the Internet, we can call them electronic contracts or contracts via Internet (Presutti Jr, W. D. 2003).

In order to systematize these characteristics of the internet. (Peleg, Lee, \& Hausman,2002). On the one hand, it is necessary to take into account the principle of objective good faith, as a discipline the civil code in its article 422 and, on the other hand, the new characteristics need to be culminated with the principle of trust, along with the already successful principle of probity. In this sense, Cláudia Lima Marques states in her text that Electronic Commerce has been consolidating itself as a new means of realizing legal relations, which defies traditional concepts of time and space (2005).

\subsection{Factors effecting E-Procurement}

E-commerce is the delivery of information, products /services or payments over telephone 
lines, computer networks or other electronic means. The term e-business, in turn, refers to more than just buy and sell. It describes the consumer services, business partners and conduction of electronic transactions within the organization. According to Weil and Vitale (2001), e-business deals with marketing activities, purchase, sale, delivery, services, and payments for products. services and information through non-proprietary networks that interconnect the company and its customers, agents, suppliers, competitors, partners and completers Before approaching the concept of electronic contract, it is important to comment on what Erica Brandini Barbagalo discusses about the various nomenclatures given to him and that, at times, can bring different connotations of what is intended. (Johnson, \& Klassen, 2005). The term "electronic" is indicative of the study made by physics of the behavior of electrical circuits. Thus, the communication of data by the computer is done by electrical impulses, it can be said then that the communication is electronic. (Johnson, \& Klassen, 2005). That is why the term "electronic contract" comes, however, it is referred to in a cyber-contract, but this expression, because it is linked to cybernetics, only to network communication, greatly limits the forms of contract. The so-called digital contracts, even bringing a connotation of contract related to computer science, do not reproduce exactly the concept of the statement that uses electronic means, but only of the language used by computer. (Chandrasekar Subramaniam, 2002) There are also so-called computer contracts, which also do not mirror what is really intended, that is, such an expression connotes that they are contracts made by the use of computers, not necessarily connected in network or connected to each other.

Another term used is a computer contract, which are simply contracts that govern the purchase and sale or lease of goods and services, such as hardware maintenance, software acquisition, etc. Thus, it is verified that computer contracts have the purpose of legal goods related to information technology, while electronic contracts themselves, in fact, have information technology as a medium for their structuring and training. The comment made by the aforementioned doctrinaire should be interpreted extensively, since the electronic contract does not only operate between the holder of a virtual establishment and the internaut, since an electronic contract can be effected between two persons, without necessarily having one of them having a virtual establishment. As an example, it is possible to mention the formation of a lending contract, in which the contractors are two individuals and none of them owns a virtual establishment.

The electronic contract not only operates between the holder of a virtual establishment and the Internet user, since an electronic contract can be effected between two physical persons, for example, having a civil character only, that is, the electronic contract will not always have the character of a consumer, and may therefore also be administrative, commercial, etc.

\subsubsection{Internal Organizational Support (IOS)}

The organizations are currently facing a dynamic similar to that of private and / or public companies in relation to the processes of transformation and internationalization, highlighting: cultural divergences; power conflicts; lack of infrastructure consistent with the new demands; 
and away from the original objectives. It is a case study that has as elements of analysis, the internal environment and context external to the institution, and the impacts of organizational transformation on its structure, processes and people. (Teo, Lin, \& Lai, 2009) The theoretical support is based on Pettigrew (1985b, 1986The article analyzes the process of organizational change of an NGO - Social Observatory Institute (IOS), whose creation is part of the efforts of national and international unions to structure innovative forms of management technologies, through the generation of knowledge.

\subsubsection{Integration with Suppliers' Electronic Systems (ISES)}

The virtual shopkeeper, when he starts to grow, finds himself at a crossroads: he needs to scale the business, better serve the customer, sell his products in physical and virtual stores, publish stocks in marketplaces and so on. At first, it does all this manually, using 1 or 2 non-integrated systems, transferring information back and forth manually or keeping it in multiple worksheets. It works, but it realizes that it needs to automate its processes or it will end up going crazy - and leaving its team crazy too - or that all the profitability will be invested in hiring an increasing team.

It is quite common for the retailer to complete the supplier evaluation process with the need to hire, on average, 3 to 4 different company systems to compose the scenario that meets the supplier, and often need to hire companies that exchange information. In a brilliant article published here at the same node E-commerce Brazil, Marcelo Linares showed with good humor the absurd comparison of a bakery being managed as an e-commerce. It addresses some very interesting items, but for didactic purposes (and to stay only on the theme that I master) we will approach, broadening the scope a little, only the challenges of the scenario involving systems.

When you have to deal with more than one system in your operation, the retailer is faced with problems of a new type. Remember, did you think all those tools would be the solution to your problems? Yeah. In some scenarios, such as small and medium-sized businesses, commercial documents are not electronically exchanged because of the low volume of documents or resources available. A possible solution to address this problem is the deployment of a Web Portal. The solution is aimed at those suppliers with a medium or low number electronic invoice issuance that allows you to enter the required data through a web form on the portal itself.

EDICOM makes it possible for large companies to enable an online system to publish their purchase orders so that their trading partners can generate and send commercial documents such as: shipping notes and invoices in order to be integrated in the ERP in the process reception. The portal allows the implementation of a bidirectional flow, being possible to send purchase orders through the solution to their suppliers automatically through the ERP. In this way, purchase orders act as base documents allowing the supplier to re-use the originating information of the order to issue the invoice. (Gunasekaran McGaughey Ngai \& Rai 2009). 
To put it into practice, a large company will provide its partners with a completely free portal. The portal is accessible via the web, by user and password. In the platform are configured the documents to be exchanged between the main actors, through validation mechanisms that guarantee that the registered information is the one required by the destination. The vendor receives an order and connects to the portal. By means of preconfigured models, the form with the data of the document and send is completed. The document is processed and sent via EDI in a standard format to integrate it with the recipient's ERP.

\subsubsection{Supplier Willingness (SW)}

Whether in the provision of services or in the commerce, the abusive practices committed by companies and merchants become more and more common and reach consumers who do not know how to identify them to denounce. In addition, says lawyer Dori Boucault, consumer rights expert, many people are victims of these abusive practices for not knowing their rights. The consumer is still considered the weakest part of the consumer relationship because he does not dominate the total knowledge, which can lead him to go through situations of obstruction of law - explains Dori Boucault.

If the consumer encounters some of these situations, you can go directly to the supplier to resolve the situation and, if you do not reach a solution, you should seek a consumer protection body in your city and state and file a complaint. This complaint must be made to the supplier in writing. When the situation goes beyond the administrative question, the consumer can hire a professional to file a lawsuit or seek the special civil court - concludes the lawyer.

The consumer expert listed what are the most common abusive practices and how to protect themselves from them. (Peleg, Lee, \& Hausman,2002). This is a very common practice that occurs when the consumer is forced to take one product while buying another. According to Boucault, this happens when the consumer has no will, but feels obligated to buy. A clear example of a married sale is when the customer hires an internet service and is required to also hire the phone service - he explains

The lawyer explains that this occurs when the supplier alleges lack of product in stock and the information is false. It ends up driving the consumer to buy another product, acting in bad faith. In addition to being abusive, this is an illegal practice, says the lawyer.

\subsubsection{Perceived Improvements to Purchasing Tasks (PIPT)}

Carrying out a company's purchases is an important task and must be performed in order to provide better results for the whole company. (Panayiotou, Gayialis, \& Tatsiopoulos, 2004). These results range from production to improvement in financial profitability indicators. For this to be possible, adopting some strategies makes the difference in the results achieved by the business. One of the most powerful strategies to improve the strategic management of purchases or strategic sourcing consists precisely in investing in personal development in search of better results. It is only through training and the constant search for knowledge 
about supply chain that it is possible to identify the critical points for the purchasing area of an organization. With this type of approach, the responsible trader can gain a broader view of what needs to be done with suppliers and purchase items to make purchasing performance indicators increasingly positive for the business.

\subsubsection{Supplier Pressure (SP)}

The sale of products with electronic signature also improves the experience of customers with brands. (Hardy, \& Williams,2008). The Caixa Seguradora, for example, noticed a quick adaptation to the digital contract model. "Customers are already accustomed to signing papers when they go to the bank, but they have become well accustomed to the idea of electronic signatures, a more agile and secure alternative. In addition to interacting with technology, customers are also able to access products that they buy faster, which increases the degree of satisfaction. Banco Inter, for example, adopted in September last year the electronic signature in the contracting of payroll-deductible loans. As a result, the completion time of the 14-day sale fell to eight days, resulting in an $18 \%$ reduction to $8 \%$ in the drop-off rate of customers seeking the product.

\section{Methodology}

\subsection{Research Design}

Research Design can be described as an outline of the methodology used by the researcher to assemble the elements of the research in a logical manner in order to find out solutions to the research problem. Research methods define "how" the research can be conducted by a particular methodology. The methodology used in this study will be an exploratory case study, which discovers the factors influencing e-procurement practices in Pakistan.

\subsection{Research Instrument}

The research instrument is a device or tool, which the researcher employs to gather data. There are multiple ways to gauge data such as interviews, psychological tests, and questionnaires. The data of this study is collected using a questionnaire as a research instrument. In other words, an adopted instrument developed by Dooley \& Purchase (2006) for determining the factors influencing e-procurement practices.

The researcher has employed a structured questionnaire adapted from the study of Dooley \& Purchase (2006) which has been used investigate the factors influencing e-procurement practices. A questionnaire is a timely, cheap and effective method for obtaining data from a large number of population. Moreover, it does not require the attendance of the researcher to collect data. Questionnaires were adapted and employed using google forms.

\subsection{Population}

The population of the study covers employees from soft drinks industries of Karachi.

\subsection{Sample}


Sample consisted of 319 respondents, among them 113 were female and 206 were male respondents. The significant number of respondents were graduated, having a university degree $(175=54.9$ per cent $)$.

\subsection{Data Collection}

After the selection and adaptation of the research instrument, the researcher developed a version of this instrument using google forms. The employees from soft drink companies Pepsi, Coca cola and Gourmet cola were contacted and then the link to the questionnaire using Google form was sent via email. The whole process took a month in total.

\subsection{Data Analyses}

Statistical Package for Social Sciences (SPSS) was employed to analyses the data set after the collection of the data. Descriptive statistics were obtained to establish the number of respondents, age and gender of the respondents. Means and standard deviations calculated based on gender, birth order and age difference were also analyzed. The internal consistency of the items was measured at two stages (the pilot testing and the final testing) to check the reliability of the instrument used to gather the data from the sampled respondents. The sampling adequacy was defined using KMO and Bartlett's Test before applying the test for construct validity. Thereafter for hypothesis testing, ANOVA test was employed.

\section{RESULTS AND FINDINGS}

\subsection{Variables}

\subsubsection{Dependent Variable}

- $\quad$ E-Procurement Intention (EPI)

\subsubsection{Independent Variable}

- Internal Organizational Support (IOS)

- Integration with Suppliers' Electronic Systems (ISES)

- $\quad$ Supplier Willingness (SW)

- $\quad$ Perceived Improvements to Purchasing Tasks (PIPT)

- $\quad$ Supplier Pressure (SP)

\subsection{Research Hypothesis}

H1: Internal Organizational Support does not impact on Electronic Procurement Intentions (EPI) - e-recruitment intention

H2: Integration with Suppliers' Electronic Systems does not impact on EPI

H3: Supplier Willingness does not impact on EPI 
H4: Perceived Improvements to Purchasing Tasks do not impact on EPI

H5: Supplier Pressure does not impact on EPI

\subsection{Descriptive Analysis}

Table 1 displays the characteristics of the respondents participated in the present study. Among the 319 respondents, 113 (35.4 per cent) were female while 206 (64.6 per cent) were male. The significant number of respondents were graduated, having a university degree (175 $=54.9$ per cent).

Table 1. Descriptive Statistics of Respondents

\begin{tabular}{ccccc}
\hline \multicolumn{5}{c}{ Gender } \\
\hline & Frequency & Percent & Valid Percent & Cumulative Percent \\
\hline Female & 113 & 35.4 & 35.4 & 35.4 \\
\hline Male & 206 & 64.6 & 64.6 & 100.0 \\
\hline \multicolumn{5}{c}{ Company } \\
\hline Gourmet Cola & 102 & 32.0 & 32.0 & 32.0 \\
\hline Coca Cola & 175 & 54.9 & 54.9 & 86.8 \\
\hline Pepsi Cola & 42 & 13.2 & 13.2 & 100.0 \\
\hline Total & 319 & 100.0 & 100.0 \\
\hline
\end{tabular}

Table 2 displays the central tendency, dispersion, and distribution of the scores received in terms of responses, having acceptable variance and other properties.

Table 2. Descriptive Statistics of Responses

\begin{tabular}{|c|c|c|c|c|c|c|}
\hline & IOS & ISES & SW & PIPT & SP & EPI \\
\hline Valid & 319 & 319 & 319 & 319 & 319 & 319 \\
\hline Missing & 0 & 0 & 0 & 0 & 0 & 0 \\
\hline Mean & 3.9619 & 4.0261 & 3.9007 & 3.8075 & 3.7220 & 3.8809 \\
\hline Std. Error of Mean & .04120 & .04696 & .04213 & .04052 & .04163 & .04279 \\
\hline Median & 4.1667 & 4.3333 & 4.0000 & 3.8000 & 3.6667 & 4.0000 \\
\hline Mode & 4.33 & 4.67 & 3.67 & 3.80 & 3.67 & 4.33 \\
\hline Std. Deviation & .73582 & .83867 & .75252 & .72368 & .74352 & .76417 \\
\hline Variance & .541 & .703 & .566 & .524 & .553 & .584 \\
\hline Skewness & -1.250 & -1.223 & -.611 & -.835 & -.551 & -.580 \\
\hline Std. Error of Skewness & .137 & .137 & .137 & .137 & .137 & .137 \\
\hline Kurtosis & 2.132 & 1.166 & .021 & 1.354 & .617 & -.046 \\
\hline Std. Error of Kurtosis & .272 & .272 & .272 & .272 & .272 & .272 \\
\hline Range & 3.67 & 3.67 & 3.33 & 4.00 & 4.00 & 3.33 \\
\hline Minimum & 1.33 & 1.33 & 1.67 & 1.00 & 1.00 & 1.67 \\
\hline Maximum & 5.00 & 5.00 & 5.00 & 5.00 & 5.00 & 5.00 \\
\hline Sum & 1263.83 & 1284.33 & 1244.33 & 1214.60 & 1187.33 & 1238.00 \\
\hline
\end{tabular}




\subsection{Reliability \& Validity}

Table 3 displays the internal consistency of the items, measured in two stages (the pilot testing and the final testing) to check the reliability of the instrument used to gather the data from the sampled respondents. The internal consistency between the items against each construct, in both stages, was found reliable and thus the instrument was declared as reliable for the further process. None of the item was considered for removal.

Table 3. Internal Consistency

\begin{tabular}{ccccc}
\hline & Pilot Test & N of Items & Final Test & N of Items \\
\hline IOS & .645 & 6 & .797 & 6 \\
\hline ISES & .592 & 3 & .634 & 3 \\
\hline SW & .658 & 3 & .711 & 3 \\
\hline PIPT & .771 & 5 & .731 & 5 \\
\hline SP & .554 & 3 & .642 & 3 \\
\hline EPI & .705 & 3 & .647 & 3 \\
\hline
\end{tabular}

The Sampling Adequacy was tested by employing KMO and Bartlett's Test using SPSS Statistics prior to testing the construct validity. Table 4 displays the output of such tests.

Table 40 Sampling Adequacy

\begin{tabular}{|c|c|c|}
\hline \multicolumn{3}{|c|}{ KMO and Bartlett's Test } \\
\hline Kaiser-Meyer-Olkin Measure & f Sampling Adequacy. & .755 \\
\hline \multirow{3}{*}{ Bartlett's Test of Sphericity } & Approx. Chi-Square & 1789.641 \\
\hline & df & 15 \\
\hline & Sig. & .000 \\
\hline
\end{tabular}

Principal Components Analysis (PCA) using SPSS Statistics was employed to test the convergent validity of the constructs used in the adopted instrument. Table 5 shows the output of PCA stating that 6 constructs were extracted. The output of PCA reveals the constructs as valid for hypotheses testing. 
Table 5. Convergent Validity

\begin{tabular}{|c|c|c|c|c|c|c|}
\hline \multicolumn{7}{|c|}{ Component Matrix } \\
\hline & \multicolumn{6}{|c|}{ Components } \\
\hline & 1 & 2 & 3 & 4 & 5 & 6 \\
\hline IOS1 & 0.698 & & & & & \\
\hline $\mathrm{IOS} 2$ & 0.719 & & & & & \\
\hline IOS3 & 0.821 & & & & & \\
\hline IOS4 & 0.619 & & & & & \\
\hline IOS5 & 0.535 & & & & & \\
\hline IOS6 & 0.579 & & & & & \\
\hline ISES1 & & 0.671 & & & & \\
\hline ISES2 & & 0.349 & & & & \\
\hline ISES3 & & 0.531 & & & & \\
\hline SW1 & & & 0.568 & & & \\
\hline SW2 & & & 0.651 & & & \\
\hline SW3 & & & 0.358 & & & \\
\hline PIPT1 & & & & 0.75 & & \\
\hline PIPT2 & & & & 0.61 & & \\
\hline PIPT3 & & & & 0.717 & & \\
\hline PIPT4 & & & & 0.747 & & \\
\hline PIPT5 & & & & 0.745 & & \\
\hline SP1 & & & & & 0.602 & \\
\hline $\mathrm{SP} 2$ & & & & & 0.697 & \\
\hline SP3 & & & & & 0.604 & \\
\hline EPI1 & & & & & & 0.349 \\
\hline EPI2 & & & & & & 0.697 \\
\hline EPI3 & & & & & & 0.649 \\
\hline
\end{tabular}

Extraction Method: Principal Component Analysis.

a. 6 components extracted. 
Table 6 shows the correlation between the items used in the instrument.

Table 6. Correlation

\begin{tabular}{|c|c|c|c|c|c|c|c|}
\hline & & IOS & ISES & SW & PIPT & SP & EPI \\
\hline \multirow{3}{*}{ IOS } & Pearson Correlation & 1 & & & & & \\
\hline & Sig. (2-tailed) & & & & & & \\
\hline & $\mathrm{N}$ & 319 & & & & & \\
\hline \multirow{3}{*}{ ISES } & Pearson Correlation & $.722^{* * *}$ & 1 & & & & \\
\hline & Sig. (2-tailed) & .000 & & & & & \\
\hline & $\mathrm{N}$ & 319 & 319 & & & & \\
\hline \multirow{3}{*}{ SW } & Pearson Correlation & $.687^{* *}$ & $.628^{* *}$ & 1 & & & \\
\hline & Sig. (2-tailed) & .000 & .000 & & & & \\
\hline & $\mathrm{N}$ & 319 & 319 & 319 & & & \\
\hline \multirow{3}{*}{ PIPT } & Pearson Correlation & $.773^{* *}$ & $.610^{* *}$ & $.638^{* *}$ & 1 & & \\
\hline & Sig. (2-tailed) & .000 & .000 & .000 & & & \\
\hline & $\mathrm{N}$ & 319 & 319 & 319 & 319 & & \\
\hline \multirow{3}{*}{ SP } & Pearson Correlation & $.532^{* *}$ & $.400^{* *}$ & $.461^{* *}$ & $.797^{* *}$ & 1 & \\
\hline & Sig. (2-tailed) & .000 & .000 & .000 & .000 & & \\
\hline & $\mathrm{N}$ & 319 & 319 & 319 & 319 & 319 & \\
\hline \multirow{3}{*}{ EPI } & Pearson Correlation & $.716^{* *}$ & $.754^{* *}$ & $.908^{* *}$ & $.661^{* *}$ & $.419^{* *}$ & 1 \\
\hline & Sig. (2-tailed) & .000 & .000 & .000 & .000 & .000 & \\
\hline & $\mathrm{N}$ & 319 & 319 & 319 & 319 & 319 & 319 \\
\hline
\end{tabular}

\subsection{Inferential Analysis}

\subsubsection{Testing Hypotheses}

Backward regression using SPSS package version 23 was employed to test the hypothesized statements. From this perspective, Table 7 depicts the overall impact of independent variables on the dependent variable. The $\mathrm{R}$ value in model 3 (Backward regression displays the last modal as the final one) shows the multiple correlation coefficient (.584), which means that with the change in the independent variables (IOS, SW, and PIPT), the dependent variable (EPI) changes regardless of negative or positive change. The R Square (R2) value in the table shows the coefficient of determination $(.341=34.1$ per cent $)$, which is the proportion of variance brought by the independent variables in the dependent variable. 


\section{Macrothink}

Table 7. Model Summary

\begin{tabular}{llrrr}
\hline Model & R & R Square & $\begin{array}{c}\text { Adjusted R } \\
\text { Square }\end{array}$ & \multicolumn{2}{c}{$\begin{array}{c}\text { Std. Error of the } \\
\text { Estimate }\end{array}$} \\
\hline 1 & $.584^{\mathrm{a}}$ & .341 & .331 & .60760 \\
\hline 2 & $.584^{\mathrm{b}}$ & .341 & .333 & .60664 \\
\hline 3 & $.584^{\mathrm{c}}$ & .341 & .335 & .60570 \\
\hline \multicolumn{2}{l}{ a. Predictors: (Constant), SP, ISES, IOS, SW, PIPT } \\
\hline \multicolumn{2}{l}{ b. Predictors: (Constant), ISES, IOS, SW, PIPT } \\
c. Predictors: (Constant), IOS, SW, PIPT \\
\hline
\end{tabular}

The model 3 in the ANOVA table (Table 8) shows the fitness of the model to regress. The F ratio in the model 3 shows that the independent variables (IOS, SW, and PIPT) statistically significantly predict the dependent variable $(\mathrm{EPI}), \mathrm{F}(3,315)=54.376, \mathrm{p}<.000$. This can be interpreted in other words as the regression model is a good fit of the data.

Table 8. ANOVA

\begin{tabular}{|c|c|c|c|c|c|c|}
\hline Model & & Sum of Squares & $\mathrm{df}$ & Mean Square & $\mathrm{F}$ & Sig. \\
\hline \multirow{3}{*}{1} & Regression & 59.859 & 5 & 11.972 & 32.428 & $.000^{\mathrm{b}}$ \\
\hline & Residual & 115.554 & 313 & .369 & & \\
\hline & Total & 175.413 & 318 & & & \\
\hline \multirow{3}{*}{2} & Regression & 59.859 & 4 & 14.965 & 40.664 & $.000^{\mathrm{c}}$ \\
\hline & Residual & 115.554 & 314 & .368 & & \\
\hline & Total & 175.413 & 318 & & & \\
\hline \multirow{3}{*}{3} & Regression & 59.848 & 3 & 19.949 & 54.376 & $.000^{\mathrm{d}}$ \\
\hline & Residual & 115.565 & 315 & .367 & & \\
\hline & Total & 175.413 & 318 & & & \\
\hline
\end{tabular}

a. Dependent Variable: EPI

b. Predictors: (Constant), SP, ISES, IOS, SW, PIPT

c. Predictors: (Constant), ISES, IOS, SW, PIPT

d. Predictors: (Constant), IOS, SW, PIPT

The model 3 in the coefficient table (table 9) displays the impact of independent variables on the e-procurement practice (EPI) intention of the participating individuals. The equation can be generated as:

$$
\text { Predicted EPI }=1.173+(.116 \times \text { IOS })+(.322 \times \text { SW })+(.281 \times \text { PIPT })
$$

Hence, it is safe to state that the variables IOS, SW, and PIPT added statistically significant and positive impact to the predicted EPI, $p<.05$ while the variables SP and ISES did not add any impact to the predicted EPI, $\mathrm{p}<.997$ and $\mathrm{p}<.862$ respectively. 
Table 9. Coefficients

\begin{tabular}{|c|c|c|c|c|c|c|c|}
\hline \multirow[t]{2}{*}{ Model } & \multicolumn{2}{|c|}{ Unstandardized Coefficients } & \multirow{2}{*}{$\begin{array}{c}\text { Standardized Coefficients } \\
\text { Beta } \\
\end{array}$} & \multirow[t]{2}{*}{$\mathrm{t}$} & \multirow[t]{2}{*}{ Sig. } & \multicolumn{2}{|c|}{ Collinearity Statistics } \\
\hline & $\mathrm{B}$ & Std. Error & & & & Tolerance & VIF \\
\hline (Constant) & 1.163 & .243 & & 4.783 & .000 & & \\
\hline IOS & .116 & .051 & .123 & 2.263 & .024 & .717 & 1.394 \\
\hline ISES & .007 & .043 & .009 & .174 & .862 & .777 & 1.286 \\
\hline SW & .318 & .056 & .327 & 5.737 & .000 & .648 & 1.543 \\
\hline PIPT & .280 & .074 & .261 & 3.780 & .000 & .442 & 2.264 \\
\hline SP & .000 & .064 & .000 & .003 & .997 & .574 & 1.743 \\
\hline (Constant) & 1.163 & .231 & & 5.038 & .000 & & \\
\hline IOS & .116 & .051 & .123 & 2.267 & .024 & .717 & 1.394 \\
\hline 2 ISES & .007 & .043 & .009 & .174 & .862 & .779 & 1.284 \\
\hline SW & .318 & .055 & .327 & 5.746 & .000 & .648 & 1.543 \\
\hline PIPT & .280 & .061 & .261 & 4.619 & .000 & .657 & 1.522 \\
\hline (Constant) & 1.173 & .224 & & 5.231 & .000 & & \\
\hline IOS & .116 & .051 & .123 & 2.287 & .023 & .720 & 1.388 \\
\hline $\mathrm{SW}$ & .322 & .052 & .330 & 6.167 & .000 & .729 & 1.371 \\
\hline PIPT & .281 & .060 & .262 & 4.672 & .000 & .664 & 1.505 \\
\hline
\end{tabular}

Table 10 reveals the overall status of the all variables in terms of their acceptance and rejection.

Table 10. Summary of Hypotheses

\begin{tabular}{clcc}
\hline No. & \multicolumn{1}{c}{ Hypotheses } & Sig value & Status \\
\hline $\mathbf{H}_{1}$ & $\begin{array}{l}\text { Internal Organizational Support does not impact on Electronic Procurement } \\
\text { Intentions (EPI) - e-recruitment intention }\end{array}$ & .023 & Rejected \\
\hline $\mathbf{H}_{2}$ & Integration with Suppliers' Electronic Systems does not impact on EPI & .862 & $\begin{array}{c}\text { Failed } \\
\text { to reject }\end{array}$ \\
\hline $\mathbf{H}_{3}$ & Supplier Willingness does not impact on EPI & .000 & Rejected \\
\hline $\mathbf{H}_{4}$ & Perceived Improvements to Purchasing Tasks do not impact on EPI & .000 & Rejected \\
\hline $\mathbf{H}_{5}$ & Supplier Pressure does not impact on EPI & .997 & $\begin{array}{c}\text { Failed } \\
\text { to reject }\end{array}$ \\
\hline
\end{tabular}

\section{Discussion and Conclusion}

Chapter five, discusses the results in according with the literature review. It provides conclusion of the study, recommend future recommendations and states the limitations, which the researcher has faced during the study.

\subsection{Discussion}

In answer to our research question, which was to investigate the factors influencing 
e-procurement practice in Pakistan. Several hypotheses, were developed in response to the research problems. Our first hypothesis stated that internal organizational support does not impact on electronic procurement intentions (epi) - e-recruitment intention The analysis fails to get the accepted, which means that internal organizational support significantly influence on electronic procurement intentions (epi). Evidence to this was given by Chandrasekar Subramaniam (2002) which states that internal organizational support assist firm electronic procurement intentions.

The researcher second hypothesis stated that integration with suppliers' electronic systems does not affect electronic procurement intentions. The results accepted the null hypothesis. There was no significant relationship found between integration with suppliers' electronic systems and electronic procurement intentions. Chang \& Wong (2010) also expressed that companies have become increasingly conscious about the integration with suppliers' electronic systems. Integration with suppliers' electronic systems has become crucial for the firms to improve electronic procurement intentions.

\subsection{Conclusion}

The concept of E-procurement has been widely spread with the growing use of informational technology in every field. Organizations are adopting methods of procurements that are more reliable, less time consuming and relatively stronger than the traditional methods. This quantitative study investigates factors influencing e-procurement practice in Karachi, Pakistan. A sample of 319 respondents was taken to observe the influence of internal organizational support, integration with suppliers' electronic systems, supplier willingness, perceived improvements to purchasing tasks and supplier pressure on e-procurement intention. The results information indicates that internal organizational support, supplier willingness and perceived improvements to purchasing tasks significantly influences e-procurement intentions. However, the factors integration with suppliers' electronic systems and supplier pressure does not have any significant impact on e-procurement intention. The result recommends the use of e-procurement system for organizations to facilitate the current practices of procurement.

\subsection{Recommendations}

The research recommends that measures and improvements must be considered for the effectiveness of existing e-procurement management system. The purpose behind these goals will not only top improve the existing practices but also identifies the needs for further development. There is a strong need for continuous monitoring and results to maintain the effectiveness of e-procurement measures. Customer's feedback should also be incorporated for the enhancement of the practices and the stakeholders must recognize the process as the process.

The study has given the lead to further researcher, and it is recommended to investigate the requirement of stakeholders. Including the viewpoints of customers, owners, workers, managerial persons, experts and authorities, suppliers and all the concern department can 
greatly enhance future performance of the container companies.

\subsection{Limitations}

This research is limited to the soft drink companies of Karachi and consist a limited sample due to the shortage of time. The results need to be more generalizable which can be done by enhancing the scope of the study and taking more number of respondents as a sample. This research also limits within Karachi only due to the accessibility issues faced by the researcher. The data including larger samples from different organizations all over Pakistan would be beneficial to develop a clearer picture regarding the factors influencing e-procurement practice in Pakistan.

\section{Acknowledgement}

Above all I want to thank to Almighty "ALLAH" who is most tolerant and kind and who makes me ready to set up this research study.

I generously appreciate my research supervisor, Sir Muhammad Asim, whose support and assistance from the beginning step to the last level permitted me to build up an understanding of the methodology of conducting research and authorised me to build up a comprehension of the approach of leading research exploration.

Also, I would like to express my gratitude to my parents, my fellow students for their support and patience, for keeping me motivated.

My research work has benefited from the insightful direction of numerous colleagues, teachers, family members and more numerous than I can fully acknowledge here. I would like to acknowledge those who contributed in the occasions that I conducted discussions to get formal feedback on my research topic that is "Factors Influencing E-Procurement Practice in Pakistan"

Lastly, I offer my respects and endowments to all those who trusted and supported me in any regard during the fulfilment of the research. study

\section{References}

Carayannis, E. G., \& Popescu, D. (2005). Profiling a methodology for economic growth and convergence: learning from the EU e-procurement experience for central and eastern European countries. Technovation, 25(1), 1-14.

Chandrasekar Subramaniam, M. J. S. (2002). A study of the value and impact of B2B e-commerce: the case of web-based procurement. International Journal of Electronic Commerce, 6(4), 19-40.

Chang, H. H., \& Wong, K. H. (2010). Adoption of e-procurement and participation of e-marketplace on firm performance: Trust as a moderator. Information \& Management, 47(5-6), 262-270. 
Chang, H. H., \& Wong, K. H. (2011). Adoption of e-procurement and participation of e-marketplace on firm performance: Trust as a moderator. Information \& Management, 47(5-6), 262-270.

Croom, S. R., \& Brandon-Jones, A. (2005). Key issues in e-procurement: procurement implementation and operation in the public sector. Journal of Public Procurement, 5(3), 367-387.

Croom, S., \& Brandon-Jones, A. (2007). Impact of e-procurement: Experiences from implementation in the UK public sector. Journal of Purchasing and Supply Management, 13(4), 294-303.

Croom, S., \& Johnston, R. (2003). E-service: enhancing internal customer service through e-procurement. International Journal of Service Industry Management, 14(5), 539-555.

Dai, Q., \& Kauffman, R. J. (2001, January). Business models for Internet-based e-procurement systems and B2B electronic markets: an exploratory assessment. In Proceedings of the 34th Annual Hawaii International Conference on System Sciences (pp. 10-pp). IEEE.

Dai, Q., \& Kauffman, R. J. (2012, January). Business models for Internet-based e-procurement systems and B2B electronic markets: an exploratory assessment. In Proceedings of the 34th Annual Hawaii International Conference on System Sciences (pp. 10-pp). IEEE.

Davila, A., Gupta, M., \& Palmer, R. (2003). Moving procurement systems to the internet:: The adoption and use of e-procurement technology models. European management journal, 21(1), 11-23.

Dooley, K., \& Purchase, S. (2006). Factors influencing e-procurement usage. Journal of Public Procurement, 6(1/2), 28-45.

Gebauer, J., \& Shaw, M. J. (2004). Success factors and impacts of mobile business applications: results from a mobile e-procurement study. International Journal of Electronic Commerce, 8(3), 19-41.

Gunasekaran, A., McGaughey, R. E., Ngai, E. W., \& Rai, B. K. (2009). E-Procurement adoption in the Southcoast SMEs. International Journal of Production Economics, 122(1), 161-175.

Hardy, C. A., \& Williams, S. P. (2008). E-government policy and practice: A theoretical and empirical exploration of public e-procurement. Government Information Quarterly, 25(2), 155-180.

Hardy, C. A., \& Williams, S. P. (2009). E-government policy and practice: A theoretical and empirical exploration of public e-procurement. Government Information Quarterly, 25(2), 155-180. 
Johnson, P. F., \& Klassen, R. D. (2005). E-procurement. MIT Sloan Management Review, $46(2), 7$.

Panayiotou, N. A., Gayialis, S. P., \& Tatsiopoulos, I. P. (2004). An e-procurement system for governmental purchasing. International journal of production economics, 90(1), 79-102.

Peleg, B., Lee, H. L., \& Hausman, W. H. (2002). Short-term e-procurement strategies versus long-term contracts. Production and Operations Management, 11(4), 458-479.

Presutti Jr, W. D. (2003). Supply management and e-procurement: creating value added in the supply chain. Industrial marketing management, 32(3), 219-226.

Quesada, G., González, M. E., Mueller, J., \& Mueller, R. (2010). Impact of e-procurement on procurement practices and performance. Benchmarking: An International Journal, 17(4), 516-538.

Subramaniam, C., \& Shaw, M. J. (2004). The effects of process characteristics on the value of B2B e-procurement. Information Technology and Management, 5(1-2), 161-180.

Teo, T. S., Lin, S., \& Lai, K. H. (2009). Adopters and non-adopters of e-procurement in Singapore: An empirical study. Omega, 37(5), 972-987.

Walker, H., \& Brammer, S. (2012). The relationship between sustainable procurement and e-procurement in the public sector. International Journal of Production Economics, 140(1), 256-268.

Wu, F., Zsidisin, G., \& Ross, A. (2007). Antecedents and outcomes of e-procurement adoption: an integrative model. IEEE Transactions on Engineering Management, 54(3), 576-587.

\section{Copyright}

Copyright for this article is retained by the author(s), with first publication rights granted to the journal.

This is an open-access article distributed under the terms and conditions of the Creative Commons Attribution license (http://creativecommons.org/licenses/by/4.0/). 